\title{
Comparing of Hydrogen On-Board Storage by the Largest Car Companies, Relevance to Prospects for More Efficient Technologies
}

\author{
Yu. S. Nechaev ${ }^{*}$, V. G. Makotchenko², M. B. Shavelkina ${ }^{3}$, M. Yu. Nechaev' ${ }^{1}$ A. Veziroglu ${ }^{4}$, \\ T. N. Veziroglu ${ }^{4}$ \\ ${ }^{1}$ I. P. Bardin Central Research Institute for Ferrous Metallurgy, Dpt. G. V. Kurdyumov Institute of Metals Science and Physics, \\ Moscow, Russia \\ ${ }^{2}$ A. V. Nikolaev Institute of Inorganic Chemistry, The Siberian Branch of the Russian Academy of Sciences, Novosibirsk, Russia \\ ${ }^{3}$ The Joint Institute for High Temperature, The Russian Academy of Sciences, Moscow, Russia \\ ${ }^{4}$ International Association for Hydrogen Energy, Miami, FL, USA \\ Email: *yuri1939@inbox.ru
}

How to cite this paper: Nechaev, Yu.S., Makotchenko, V.G., Shavelkina, M.B., Nechaev, M.Yu., Veziroglu, A. and Veziroglu, T.N. (2017) Comparing of Hydrogen OnBoard Storage by the Largest Car Companies, Relevance to Prospects for More Efficient Technologies. Open Journal of Energy Efficiency, 6, 73-79.

https://doi.org/10.4236/ojee.2017.63005

Received: April 3, 2017

Accepted: July 29, 2017

Published: August 1, 2017

Copyright (c) 2017 by authors and Scientific Research Publishing Inc. This work is licensed under the Creative Commons Attribution International License (CC BY 4.0).

http://creativecommons.org/licenses/by/4.0/

\begin{abstract}
It presented a comparative consideration of General Motors long-term activities on the current subject of fuel-cell-powered electric vehicles vs Toyota Mirai recent results, relevant to prospects on more efficient and safe technologies of the hydrogen on-board storage. It also presented a call on the project International cooperation. The main aim of this paper is to attract attention of General Motors, Toyota and/or other large car companies to a real possibility of developing and using, in the nearest future, of the break-through hydrogen on-board storage technology based on the solid $\mathrm{H}_{2}$ intercalation into graphite nanostructures.
\end{abstract}

\section{Keywords}

GM' Activities vs Toyota Mirairesults, Prospects on Developing of a Break-Through Hydrogen On-Board Storage Technology, The Solid $\mathrm{H}_{2}$ Intercalation into Graphite Nanostructures, Call on the Project International Cooperation

\section{Introduction}

In the connection with the intensive working out of the current subject of fuel-cell-powered electric vehicles in different countries, a comparative consideration is expedient of General Motors long-term (from 1964 up to nowadays [1]) activities vs Toyota Mirai recent results (from 1993 up to nowadays [2]), re- 
levant to prospects on more efficient technologies of the hydrogen on-board storage. It is necessary to emphasize that Toyota and General Motors, during the long-term period, have been among the largest car companies in the World, and they have also been in a perpetual rivalry.

\section{About Toyota Mirairecent Results}

As is noted in [2] [3], the automaker has been selling the Toyota Mirai in Japan since December 2014, but began sales in California in October 2015-marking the first time hydrogen-powered vehicles were sold in the United States. A Toyota spokesperson told Tech Insider that Toyota plans to sell 30,000 a year worldwide by 2020 .

Toyota Mirai has the following characteristics [2] [3]:

1) power output $153 \mathrm{HP}(114 \mathrm{~kW})$;

2) two carbon fiber high-pressure tanks for hydrogen on-board storage;

3) fuel compressed $\mathrm{H}_{2}$ gas maximum filling pressure $87.5 \mathrm{MPa}$;

4) normal operating pressure $70 \mathrm{MPa}$;

5) hydrogen storage density (capacity) 5.7 weight \%;

6) hydrogen storage mass about $5.0 \mathrm{~kg}$;

7) the driving range at 312 miles.

\section{About General Motors Long-Term Activities and Recent Results}

Recently, GM has delivered fuel cell military vehicle-the Colorado ZH2, along with the US Army Tank Automotive Research, Development and Engineering Center [1] [3] [4]. It is the most extreme off-road-capable fuel-cell-powered electric vehicle ever from GM. The Colorado ZH2 fuel cell vehicle is undergoing the extreme military testing in 2017 [5].

GM says [4] that the test vehicle would get a bit less than 200 miles of driving range from the fuel cell. But over time, with newer fuel cells, the range could double. Some of the Colorado gear GM is using isn't the absolute latest technology, but that's intentional, because it has already been certified and GM wants to spend the 2017 year testing, not waiting for approvals then hasty testing. Built on a modified Chevrolet Colorado chassis, the vehicle contains several technologies that may one day change the auto industry [3] [4] [5].

\section{On Solving the Current Problem of the Effective and Safe Hydrogen On-Board Storage}

Despite the above noted Toyota and General Motors results [1] [3] [4] [5], along with results of other large car companies [2], the problem of the effective and safe hydrogen on-board storage has yet been under consideration of a number of scientists, for instance, [6]-[12].

In this connection, it is expedient to attract attention of both the scientists and the car companies to a real possibility of developing of a break-through hydro- 
gen on-board storage technology of intercalation of solid molecular hydrogen of a high density into graphite nanofibers. It could be one of the problem solution ways.

The technology physics has been developed in [13] [14] [15] [16] [17] on the basis of the thermodynamic analysis [18] [19] of a large massive of the related experimental and theoretical data, including [20]-[31] ones.

A related microphotograph of hydrogenated graphite nanofibers is shown in Figure 1 (taken from [13] [15]). A comparison of this possible break-through technology [13] [14] [15] [16] [17] with the known ones is presented in Figure 2 (taken from [13] [15]). Hence, a related International research project (see the next Item) seems rather expedient.

\section{Synopsis of the International Research Project \\ "Thermodynamic Aspects of Hydrogen Sorption and Intercalation in Nanostructured Carbon-Based Materials, Relevance for Clean Energy Applications"}

The project is devoted to the definition of thermodynamic characteristics and

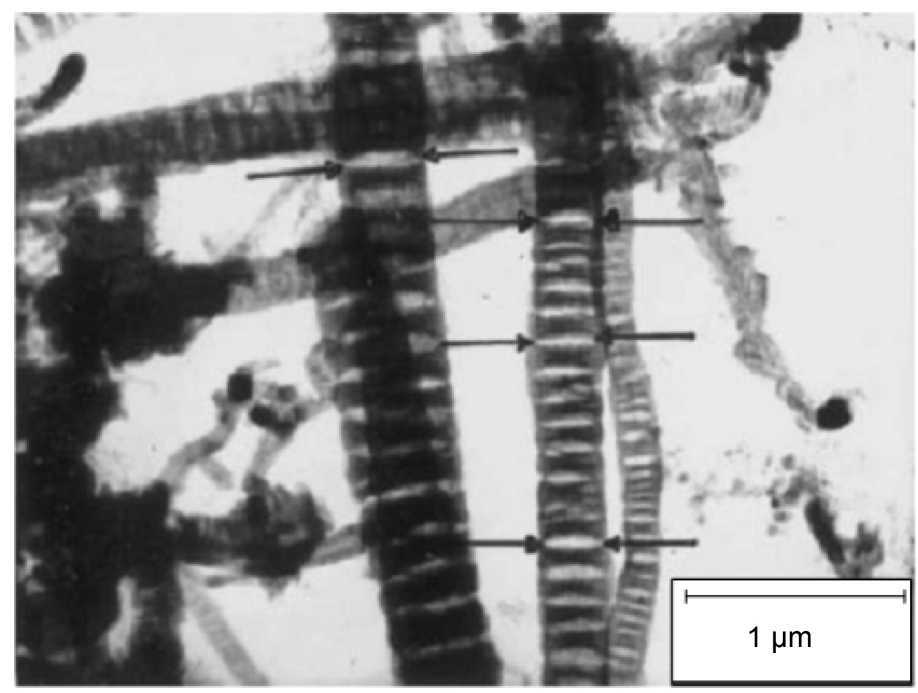

Figure 1. Micrograph of hydrogenated graphite nanofibers (GNFs) with Pd-catalyst (hydrogenated at $300 \mathrm{~K}$ and initial pressure of $P_{(\mathrm{H} 2 \mathrm{gas})} \approx$ $8 \mathrm{MPa}$ ) after release from them, at $300 \mathrm{~K}$ for $10 \mathrm{~min}$ according to data [21]\}, of the intercalated solid $\mathrm{H}_{2}$ nanophase (17 mass. \%) of a high density of $\rho_{\mathrm{H} 2} \approx 0.5 \mathrm{~g} / \mathrm{cm}^{3}$ (analysisresults [14] [15] [16] [17]). The arrows in the picture indicate some of the slit-like closed nanopores of the lens shape, where the solid $\mathrm{H}_{2}$ intercalated nanophase (under pressure of $\sim 50 \mathrm{GPa}$ ) was localized (according to [14] [15] [16] [17]). Such a pressure level can be also evaluated by the consideration of the material deformation and the necessary stresses for forming such lens shape closed nanopores at the expense of the energy of association of penetrating (into the nanopores) hydrogen atoms to molecules "captured" inside the nanopores [14] [15] [16] [17]\}. It may be considered as an extraordinary manifestation of both the Kurdjumov-like effect, and the spillover effect [14] [16]. 


\section{Mass and Volume Densities}

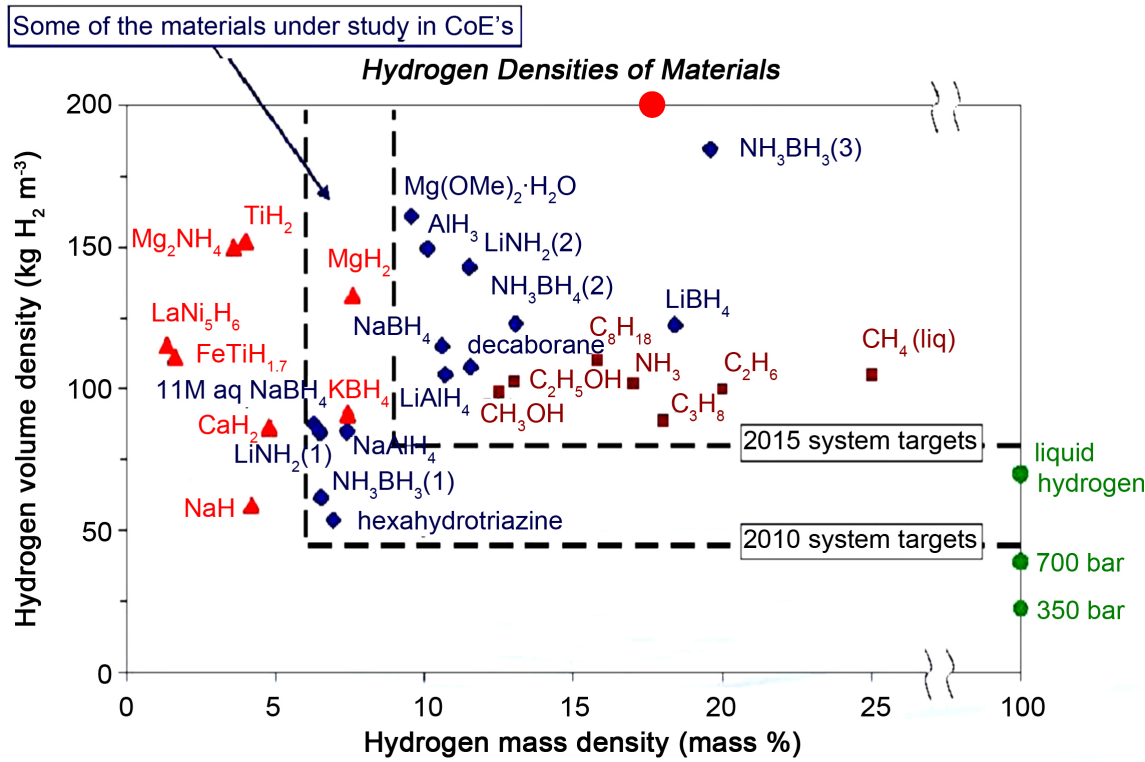

Figure 2. It is shown (in the face of known achievements) US DOE system targets for 2010 and 2015, relevant to gravimetric and volumetric hydrogen on-board storage densities. The large red circle is related to the possible break-through technology [13] [14] [15] [16] [17] of the solid molecular hydrogen intercalation into the hydrogenated separate graphite nanofibers (see Figure 1).

the disclosure of the atomic mechanisms of processes of hydrogen sorption and intercalation in expanded graphite and graphene materials. It is related to the current unresolved problems of the clean energy, including the problem of a compact and safe storage of hydrogen in eco-cars [6]-[17].

In the project three methods of synthesis of carbon nanostructures will be used: 1) a method of destructive thermal decomposition of some intercalated in graphite compounds based on polyfluoride carbon; 2) plasma jet method, based on the pyrolysis of carbon-containing materials in a DC plasma torch; 3) the method of chemical vapor deposition.

The conventional experimental techniques will be used for the identification and the characterization of the synthesized nanostructures (X-ray diffraction, thermogravimetry, electron microscopy, Raman spectroscopy, etc.).

For obtaining the project research results, the following will be used: 1) the unique technology of hydrogenation of carbon materials and nanomaterials in a gas at a pressure of molecular hydrogen up to $30 \mathrm{MPa}$ and temperatures up to $870 \mathrm{~K}$, as well as the technology of hydrogenation by superthermal hydrogen atoms; 2) methods of thermogravimetric analysis and thermal desorption analysis (with using the original developments [18] [19]) of hydrogenated materials and nanomaterials; 3) approaches and methods [14]-[19] of thermodynamic analysis of the experimental data obtained by the project participants, and comparison of the test results with the related theoretical and experimental data of other researchers to reveal the atomic mechanisms of the hydrogensorption and 
intercalation processes.

By using these methods, it will be determined the thermodynamic characteristics of hydrogen sorption (hydrogen concentrations, the equilibrium constants, the standard enthalpy changes, the activation volumes, the rate constants, the activation energies) and disclosed the atomic mechanisms of sorption for different hydrogen states in the expanded graphite (the first time) and graphene materials.

The further research of the physics [13] [14] [15] [16] [17] of intercalation of the solid, liquid or gaseous molecular hydrogen of a high density in the carbon nanostructures will be held.

At the first time, the experimental study of the possibility of intercalation of the high-density molecular hydrogen in compacted expanded graphite and multilayer graphene will be held.

The development of prospects of the advance technology of effective and safe storage of intercalated high density hydrogen in carbon nanomaterials and their urgent in the field of hydrogen energy applications will be determined.

\section{Conclusion}

There are reasons, including [13] [25] study results, to attract attention of General Motors, Toyota and/or other large car companies to a real possibility of developing and using, in the nearest future, of the break-through hydrogen onboard storage technology (Figure 1 and Figure 2).

The further studies of the physics [14] [15] [16] [17] of such a possible unique technology are expedient, may be, within the project International cooperation.

\section{References}

[1] CHFCA Weekly Fuel (2016) News, GM Marks 50 Years of Fuel Cell Research. CHFCA Weekly Fuel, Vancouver.

[2] Muoio, D. (2016) 8 Hydrogen-Powered Cars in the Works Right Now. CHFCA Weekly Fuel, Vancouver.

[3] Posluszny, R. (2015) What It's Really Like Driving a Hydrogen Fuel Cell Car. The Toyota Mirai Is Full of Surprises. CHFCA Weekly Fuel, Vancouver.

[4] CHFCA Weekly Fuel (2016) News, Chevrolet's Next Fuel Cell Concept Is Unlike Any You've Seen Before. CHFCA Weekly Fuel, Vancouver.

[5] Goldberg, M. (2017) Chevrolet's Hydrogen Fuel Cell-Powered Colorado ZH2 Undergoing Testing at Fort Carson. CHFCA Weekly Fuel, Vancouver.

[6] Callini, E., Aguey-Zinsou, K.-F., Ahuja, R., Ares, J.R., Bals, S., Biliškov, N., Chakraborty, S., Charalambopoulou, G., Chaudhary, A.-L., Cuevas, F., Dam, B., de Jongh, P., Dornheim, M., Filinchuk, Y., Novaković, J.G., Hirscher, M., Jensen, T.R., Jensen, P.B., Novaković, N., Lai, Q., Leardini, F., Gattia, D.M., Pasquini, L., Steriotis, T., Turner S. and Vegge, T. (2016) Nanostructured Materials for Solid-State Hydrogen Storage: A Review of the Achievement of COST Action MP1103. International Journal of Hydrogen Energy, 41, 14404-14428. https://doi.org/10.1016/j.ijhydene.2016.04.025

[7] Niaz, S., Manzoor, T. and Pandith, A.H. (2015) Hydrogen Storage: Materials, Me- 
thods and Perspectives. Renewable and Sustainable Energy Reviews, 50, 457-469. https://doi.org/10.1016/j.rser.2015.05.011

[8] Ozturk, Z., Baykasoglu, C. and Kirca, M. (2016) Sandwiched Graphene-Fullerene Composite: A Novel 3-D Nanostructured Material for Hydrogen Storage. International Journal of Hydrogen Energy, 41, 6403-6411.

https://doi.org/10.1016/j.ijhydene.2016.03.042

[9] Ting, V.P., Ramirez-Cuesta, A.J., Bimbo, N., Sharpe, J.E., Noguera-Diaz, A., Presser, V., Rudic, S. and Mays, T.J. (2015) Direct Evidence for Solid-Like Hydrogen in a Nanoporous Carbon Hydrogen Storage Material at Supercritical Temperatures. ACS NANO, 9, 8249-8254. https://doi.org/10.1021/acsnano.5b02623

[10] Lee, H., Choi, Y.N., Choi, S.B., Kim, J., Kim, D., Jung, D.H., Park, Y.S. and Yoon, K.B. (2013) Liquid-Like Hydrogen Stored in Nanoporous Materials at $50 \mathrm{~K} \mathrm{Ob}$ served by in situ Neutron Diffraction Experiments. Journal of Physical Chemistry $C$, 117, 3177-3184. https://doi.org/10.1021/jp3128065

[11] Gallego, N.C., He, L.L., Saha, D., Contescu, C.I. and Melnichenko, Y.B. (2011) Hydrogen Confinement in Carbon Nanopores: Extreme Densification at Ambient Temperature. Journal of the American Chemical Society, 133, 13794-13797. https://doi.org/10.1021/ja202432x

[12] Tozzini, V. and Pellegrini, V. (2013) Prospects for Hydrogen Storage in Graphene. Physical Chemistry Chemical Physics, 15, 80-89. https://doi.org/10.1039/C2CP42538F

[13] Nechaev, Y.S., Yurum, A., Tekin, A., Yavuz, N.K., Yurum, Yu. And Veziroglu, T.N. (2014) Fundamental Open Questions on Engineering of Super Hydrogen Sorption in Graphite Nanofibers: Relevance for Clean Energy Applications. American Journal of Analytical Chemistry, 5, 1151-1165. https://doi.org/10.4236/ajac.2014.516122

[14] Nechaev, Y.S. and Veziroglu, T.N. (2015) Mechanism and Energetics of the Unique Spillover Effect Manifestation, Relevance to the Efficient Hydrogen Storage in Graphite Nanofibers. International Journal of Chemistry, 7, 207-212. https://doi.org/10.5539/ijc.v7n2p207

[15] Nechaev, Y.S. and Veziroglu, T.N. (2015) On the Hydrogenation-Dehydrogenation of Graphene-Layer-Nanostructures: Relevance to the Hydrogen on-Board Storage Problem. International Journal of Physical Sciences, 10, 54-89. https://doi.org/10.5897/IJPS2014.4212

[16] Nechaev, Y.S., Filippova, V.P., Tomchuk, A.A., Yurum, A., Yurum, Y. and Veziroglu, T.N. (2016) On the Spillover Effect of the Solid $\mathrm{H}_{2}$ Intercalation into Graphite Nanofibers. Nanosystems: Physics, Chemistry, Mathematics, 7, 204-209.

[17] Nechaev, Y.S., Filippova, V.P., Yurum, A., Yurum, Y. and Veziroglu, T.N. (2015) The Reversible Hydrogenation-Dehydrogenation of Membrane and Epitaxial Graphenes. Journal of Chemical Engineering and Chemical Research, 2, 421-457.

[18] Nechaev, Y.S. (2006) The Nature, Kinetics, and Ultimate Storage Capacity of Hydrogen Sorption by Carbon Nanostructures. Physics-Uspekhi, 49, 563-591. https://doi.org/10.1070/PU2006v049n06ABEH002424

[19] Nechaev, Y.S. (2010) Carbon Nanomaterials, Relevance to the Hydrogen Storage Problem. Journal of Nanoparticle Research, 12, 1-44. https://doi.org/10.4028/www.scientific.net/JNanoR.12.1

[20] Chambers, A., Park, C., Baker, R.T.K. and Rodriguez, N.M. (1998) Hydrogen Storage in Graphite Nanofibers. The Journal of Physical Chemistry B, 102, 4253-4256. https://doi.org/10.1021/jp9801141

[21] Park, C., Anderson, P.E., Chambers, A., Tan, C.D., Hidalgo, R. and Rodriguez N.M. 
(1999) Further Studies of the Interaction of Hydrogen with Graphite Nanofibers. The Journal of Physical Chemistry B, 103, 10572-10581. https://doi.org/10.1021/jp990500i

[22] Rodriguez, N.M. and Baker, R.T.K. (1997) Storage of Hydrogen in Layered Nanostructures. US Patent No. 5653951.

[23] Rodriguez, N.M. and Baker, R.T.K. (2000) Method for Introducing Hydrogen into Layered Nanostructures. US Patent No. 6159538.

[24] Baker, R.T.K. (2005) Encyclopedia of Materials: Science and Technology, Elsevier, Amsterdam, $932 \mathrm{p}$.

[25] Maeland, A.J. (2002) The Storage of Hydrogen for Vehicular Use-A Review and Reality Check. International Science Journal for Alternative Energy and Ecology, 1, 19-29.

[26] Gupta, B.K. and Srivastava, O.N. (2000) Synthesis and Hydrogenation Behavior of Graphitic Nanofibers. International Journal of Hydrogen Energy, 25, 825-830. https://doi.org/10.1016/S0360-3199(99)00104-4

[27] Gupta, B.K. and Srivastava, O.N. (2001) Further Studies on Microstructural Characterization and Hydrogenation Behavior of Graphitic Nanofibers. International Journal of Hydrogen Energy, 26, 857-862. https://doi.org/10.1016/S0360-3199(01)00021-0

[28] Gupta, B.K., Tiwari, R.S. and Srivastava, O.N. (2004) Studies on Synthesis and Hydrogenation Behavior of Graphitic Nanofibers Prepared through Palladium Catalyst Assisted Thermal Cracking of Acetylene. Journal of Alloys and Compounds, 381, 301-308. https://doi.org/10.1016/j.jallcom.2004.03.094

[29] Gupta, B.K. and Srivastava, O.N. (2006) New Carbon Variants: Graphitic Nanofibers (Nano-Springs, Nano-Shockers) as Hydrogen Storage Materials. International Science Journal for Alternative Energy and Ecology, 5, 63.

[30] Rzepka, M., Bauer, E., Reichenauer, G., Schliermann, T., Bernhardt, B., Bohmhammel, K., Henneberg, E., Knoll, U., Maneck, H.-E. and Braue, W. (2005) Hydrogen Storage Capacity of Catalytically Grown Carbon Nanofibers. The Journal of Physical Chemistry B, 109, 14979-14989. https://doi.org/10.1021/jp051371a

[31] Reichenauer, G., Rzepka, M., Bauer, E., Schliermann, T., Bernhardt, B., Bohmhammel, K., Henneberg, E., Knoll, U., Maneck, H.-E. and Braue, W. (2006) Hydrogen Storage Capacity of Catalytically Grown Carbon Nanofibers. Proceedings of International Conference on Carbon, The Robert Gordon University, Aberdeen, Scotland, 6-21 July 2006. 
Submit or recommend next manuscript to SCIRP and we will provide best service for you:

Accepting pre-submission inquiries through Email, Facebook, LinkedIn, Twitter, etc. A wide selection of journals (inclusive of 9 subjects, more than 200 journals)

Providing 24-hour high-quality service

User-friendly online submission system

Fair and swift peer-review system

Efficient typesetting and proofreading procedure

Display of the result of downloads and visits, as well as the number of cited articles Maximum dissemination of your research work

Submit your manuscript at: http://papersubmission.scirp.org/

Or contact ojee@scirp.org 